\title{
Pengaruh Model Pembelajaran Talking Stick Berbantu Media Papegi terhadap Hasil Belajar Matematika
}

\author{
*Riana Ulfa Sadiah¹, Supandi², Kiswoyo ${ }^{3}$
}

123 Universitas PGRI Semarang, Semarang, Indonesia

\author{
A R T I C L E I N F 0 \\ Article history: \\ Received 10 May 2019 \\ Received in revised form \\ 10 June 2019 \\ Accepted 15 July 2019 \\ Available online 29 August \\ 2019 \\ Kata Kunci: \\ talking stick, papegi, hasil \\ belajar \\ Keywords: \\ talking stick, papegi, \\ learning outcomes.
}

\begin{abstract}
A B S T R A K
Penelitian ini secara umum bertujuan untuk mengetahui pengaruh model pembelajaran Talking Stick berbantu media PAPEGI (Papan Perkalian Pembagian) terhadap hasil belajar matematika siswa kelas II SD. Berdasarkan hasil observasi, dimana hasil belajar matematika siswa masih rendah. Jenis penelitian ini adalah penelitian eksperimen dengan pendekatan kuantitatif. Desain penelitian yang digunakan dalam penelitian ini adalah Pre-Eksperimental Design dengan bentuk One Grup Pretest-Posttest Design. Populasi penelitian ini adalah seluruh siswa kelas II SD dengan menggunakan teknik Non Probability Sampling yang merupakan jenis sampling jenuh. Data dalam penelitian ini diperoleh melalui tes, observasi dan dokumentasi. Analisis data menggunakan teknik analisis uji normalitas awal akhir, uji hipotesis (uji t. uji normalitas digunakan untuk mengetahui hasil belajar siswa tersebut berdistribusi normal atau tidak. Uji hipotesis menggunakan t-test.
\end{abstract} Berdasarkan hasil analisis data penelitian menunjukkan koefisien uji t sebesar 18,856 dan koefisien tersebut signifikan pada taraf $5 \%$. Rata-rata nilai sebelum diberi perlakuan adalah 56,1 yang berarti kurang dari KKM dan rata-rata nilai setelah diberi perlakuan adalah 82,4 yang berarti sudah memenuhi KKM. Selisih rata-rata kenaikannya sebesar 26,3. Oleh karena itu dapat disimpulkan bahwa bahwa model pembelajaran talking stick berbantu media PAPEGI berpengaruh terhadap hasil belajar matematika siswa kelas II SD.

\section{A B S T R A C T}

The Talking Stick learning model with the help of PAPEGI media (Multiplication Board) on the mathematics learning outcomes of second grade students at SD. This type of research was quantitative and experimental research. The research design in this study was Pre-Experimental Design in the form of One Group Pretest-Posttest Design. The population of this study was all students of second grade at SD by Non Probability Sampling technique which saturated sampling. The data in this study obtained through tests, observation and documentation. Data analyzed by the final initial normality test analysis technique, hypothesis testing (t test. Normality test used to test the student's learning outcomes normally distributed or not. Hypothesis tested by the t-test. This significant level was 5\%. The average before being given permission was 56.1 which means less than KKM and the average score after receiving assistance was 82.4 which means that it fulfilled KKM. The average increase was 26.3 Therefore it can be concluded that the learning model of learning still helps PAPEGI media participation towards the mathematics learning outcomes of second grade at $S D$.

\section{Pendahuluan}

Menurut Sistem Pendidikan Nasional (Undang-Undang Repubik Indonesia nomor 20 Tahun 2003 bab 1 pasal 1) pendidikan adalah usaha sadar dan terencana untuk mewujudkan suasana belajar dan proses pembelajaran agar peserta didik secara aktif mengembangkan potensi dirinya untuk memiliki kekuatan spiritual keagamaan, pengendalian diri, kepribadian, kecerdasan, akhlak mulia, serta keterampilan yang diperlukan dirinya, masyarakat, bangsa dan negara.

Copyright @ Universitas Pendidikan Ganesha. All rights reserved. 
Sedangkan menurut Dictionary of Education dalam Sudharto, Suharno, \& Soegeng (2013:5) pendidikan adalah proses dimana seseorang mengembangkan kemampuan, sikap, dan bentuk-bentuk tingkah laku lainnya di dalam masyarakat, dimana dia hidup. Maka dari itu pemerintah selalu berupaya untuk meningkatkan kualitas pendidikan yang ada di Indonesia. Hal itu sejalan dengan Undang - Undang No. 20 Tahun 2003 bab II pasal 3 menyatakan bahwa pendidikan berfungsi mengembangkan kemampuan dan membentuk watak serta peradaban bangsa yang bermartabat dalam rangka mencerdaskan kehidupan bangsa. Untuk itu pendidikan nasional bertujuan untuk mengembangkan potensi peserta didik agar menjadi manusia yang beriman dan bertakwa kepada Tuhan Yang Maha Esa, berakhlak mulia, sehat dan berilmu, cakap, kreatif, mandiri dan menjadi warga negara yang demokratis dan bertanggungjawabUndang-undang inilah yang menjadi dasar berdirinya proses pendidikan yang ada di Negara Indonesia.

Peran pendidikan sangat penting sekali bagi peserta didik baik untuk masa sekarang ataupun untuk menyongsong masa yang akan datang. Keberhasilan suatu pendidikan tidak lepas dari peranan penting seorang pendidik dan bagaimana pendidik itu mendidik peserta didik. Matematika merupakan salah satu mata pelajaran yang sangat penting. Di dalam kehidupan sehari-hari kita seringkali menjumpai masalah-masalah yang berkaitan dengan matematika (hitung-hitungan). Terutama pada masalah operasi hitung baik penjumlahan, pengurangan, perkalian ataupun pembagian. Menurut Susanto (2016:185) matematika merupakan salah satu disiplin ilmu yang dapat meningkatkan kemampuan berpikir dan beragumentasi, memberikan kontribusi dalam penyelesaian masalah sehari-hari, serta memberikan dukungan dalam pengembangan ilmu pengetahuan dan dan teknologi (Cahyani,dkk, 2019:Janah, 2018:Anggarini, 2019). Pentingnya matematika tidak hanya digunakan untuk keperluan sehari-hari saja, namun juga untuk mendukung ilmu pengetahuan lainnya. Oleh karena itu, matematika perlu dikuasai, terutama di sekolah dasar yang merupakan tempat pertama kali anak mengenyam pendidikan.

Namun kenyataannya sebagian besar siswa tidak menyukai mata pelajaran matematika karena mata pelajaran matematika itu sulit. Matematika memiliki sifat abstrak, keabstrakan itulah yang membuat matematika sulit dipelajari oleh siswa (Amir, 2014:). Cara penyelesaian masalah matematika yang membingungkan membuat siswa malas untuk belajar. Siswa juga masih kesulitan dalam memahami konsep matematika. Di SD N Pleburan 04 Kota Semarang siswa kurang tertarik dalam mengikuti pembelajaran matematika karena sudah tertanam pada diri mereka bahwa matematika itu sulit. Dan juga pemahaman siswa terhadap mata pelajaran matematika masih kurang terutama pada materi operasi hitung perkalian dan pembagian. Akibatnya hasil belajar siswa menjadi rendah dan kurang memuaskan. Hal ini terbukti dari hasil perolehan nilai harian siswa yang masih di bawah KKM. Kriteria Ketuntasan Minimal (KKM) pada mata pelajaran matematika kelas II di SD Negeri Pleburan 04 Semarang yaitu 65. Dilihat dari hasil perolehan nilai harian matematika banyak yang masih mendapat nilai di bawah KKM.

Rendahnya hasil belajar matematika siswa kelas II disebabkan oleh guru yang belum menggunakan media pembelajaran secara maksimal atau hanya menggunakan media buku paket saja dalam menjelaskan materi sehingga siswa masih merasa kesulitan dalam memahami materi, pembelajaran masih berpusat pada guru bukan berpusat pada siswa. Pada pembelajaran guru juga masih menggunakan model konvensional jadi siswa kurang tertarik dalam mengikuti pembelajaran, pembelajaran jadi sangat membosankan bagi siswa. Oleh sebab itu, perlu adanya upaya untuk menarik minat siswa dalam mengikuti pembelajaran matematika. Ada banyak cara yang dapat dilakukan guru untuk menarik minat siswa. Salah satu yang mampu membuat anak berminat mengikuti pembelajaran matematika adalah dengan membuat proses pembelajaran matematika menyenangkan.

Hasil belajar siswa dapat meningkat bila dilakukan suatu pembelajaran yang efektif dan efisien yaitu dengan menggunakan model atau metode pembelajaran yang bisa meningkatkan aktifitas siswa dalam pembelajaran serta menjadikan pembelajaran lebih menarik dan menyenangkan. Agar pembelajaran di dalam kelas lebih menarik perlu adanya penerapan model atau metode pembelajaran. Pengajar bukan hanya menyampaikan pembelajaran tetapi pengajar harus bisa menciptakan suasana pembelajaran yang aktif dan menyenangkan sehingga terjadi keseimbangan dipihak guru maupun peserta didik. Untuk memperbaiki kondisi tersebut guru perlu melakukan pembaharuan dalam strategi belajar mengajar yang diterapkan di kelas. Tidak hanya menciptakan suasana pembelajaran yang menyenangkan dan membuat peserta didik menjadi aktif dalam proses pembelajaran. Dalam suatu pembelajaran ada suatu tujuan yang harus tercapai yaitu materi pembelajaran harus dapat tersampaikan dengan baik dan dapat dipahami oleh semua peserta didik.

Menurut Joyce dan Weil dalam Rusman (2017:244) berpendapat bahwa model pembelajaran adalah suatu rencana atau pola yang dapat digunakan untuk membentuk kurikulum (rencana pembelajaran jangka panjang), merancang bahan-bahan pembelajaran, dan membimbing pembelajaran di kelas atau yang lain. Model pembelajaran dapat dijadikan pola pilihan, artinya para guru boleh memilih model pembelajaran yang sesuai, efektif, dan efisien untuk mencapai tujuan pembelajaran yang 
diharapkan (Wijanarko, 2017). Salah satu model pembelajaran yang menarik dan menyenangkan adalah model pembelajaran Talking Stick. Menurut Wulansari (2017) Model pembelajaran Talking Stick merupakan salah satu model pembelajaran kooperatif. Model ini dilakukan dengan bantuan tongkat. Tongkat tersebut nantinya akan dijadikan sebagai giliran untuk berpendapat / menjawab pertanyaan dari guru setelah siswa mempelajari materi pelajaran. Model pembelajaran ini secara umum diterapkan pada jenjang sekolah dasar (Huda, 2017).

Selain menggunakan model pembelajaran Talking Stick, penelitian ini juga menggunakan media pembelajaran untuk memudahkan siswa dalam memahami materi pembelajaran. Yaitu media PAPEGI (Papan Perkalian Pembagian). Media pembelajaran PAPEGI (Papan Perkalian Pembagian) merupakan inovasi dari permainan congklak dimana cara penggunaannya seperti bermain congklak. Hanya saja modelnya dibuat seperti papan yang terdapat beberapa persegi (sebagai lubang) dan dibantu dengan benda manipulatif yaitu stick ice cream untuk menjalankan permainannya, maka dari itu dinamakan papan perkalian pembagian (PAPEGI). Benda manipulatif dimaksud untuk mengubah konsep abstrak matematika menjadi konkret agar lebih mudah dipahami oleh siswa. Dengan media PAPEGI ini siswa akan belajar operasi hitung perkalian dan pembagian dengan mudah dan menyenangkan karena sambil bermain.

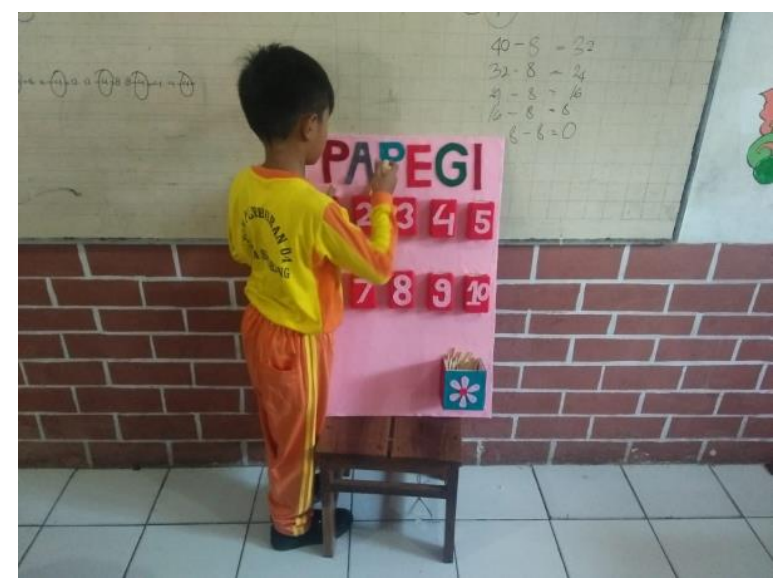

Gambar 1.

Siswa Menggunakan Media PAPEGI

Penelitian ini dilaksanakan dengan tujuan untuk mengetahui pengaruh model pembelajaran talking stick berbantu media PAPEGI terhadap hasil belajar matematika siswa kelas II SD N Pleburan 04 Kota Semarang. Penelitian dilaksanakan di SD N Pleburan 04 Kota Semarang tahun ajaran 2018/2019 pada kelas II dengan jumlah siswa sebanyak 37 siswa. Jenis peneitian yang dilakukan menggunakan desain eksperimen dengan jenis one group pretest posttest design. Dalam desain ini terdapat pretest sebelum adanya perlakuan untuk mengetahui kondisi awal siswa dan postest untuk mengetahui hasil belajar setelah diberi perlakuan yaitu pembelajaran dengan menggunakan model pembelajaran Talking Stick berbantu media PAPEGI.

Dengan adanya permasalahan ini diajukan sebuah model pembelajaran yang berbantu media yaitu model pembelajaran talking stick berbantu media PAPEGI untuk kelas II. Pengajuan berdasarkan permasalahan yang ada dikelas II SD N Pleburan 04 Kota Semarang yaitu hasil belajar matematika siswa rendah khususnya pada materi perkalian dan pembagian. Faktor dari hasil belajar rendah tersebut siswa kurang memahami materi pembelajaran dan tertarik terhadap poses pembelajaran. Untuk itu perlu adanya media pembelajaran untuk membantu siswa lebih mudah dalam memahami materi pembelajaran. Dengan media PAPEGI (Papan Perkalian dan Pembagian) siswa menjadi lebih mudah memahami materi perkalian dan pembagian yaitu menghitung perkalian dan pembagian dengan menggunakan benda konkrit (stick) secara berulang. Dengan model pembelajaran Talking Stick siswa menjadi lebih aktif dalam mengikuti pembelajaran.

\section{Metode}

Penelitian ini dilaksanakan di SD N Pleburan 04 Kota Semarang. Penelitian ini dilakukan pada tanggal 2 Mei sampai 4 Mei 2019 pada tahun pembelajaran 2018/2019.

Dalam penelitian ini terdapat dua variabel, yaitu variabel bebas dan variabel terikat: 1) Variabel Bebas (X), Variabel X pada penelitian ini adalah model pembelajaran Talking Stick berbantu media PAPEGI 
(Papan Perkalian Pembagian), 2) Variabel Terikat (Y), untuk variabel Y pada penelitian ini adalah hasil belajar matematika siswa kelas II.

Metode yang digunakan dalam penelitian ini adalah metode penelitian eksperimen menggunakan Pre-Experimental Designs (nondesigns) dengan bentuk One-Group Pretest-Posttest Design. Populasi dalam penelitian ini adalah siswa kelas II SD N Pleburan 04 tahun pelajaran 2018/2019 yang terdiri dari satu kelas dengan jumlah populasi yang akan diteliti sebanyak sebanyak 37 siswa. Karena populasi dalam penelitian ini jumlah subyeknya kurang dari 100 siswa, maka sampel dari penelitian ini adalah sama dengan populasi yang diteliti yaitu siswa kelas II SD N Pleburan 04 tahun pelajaran 2018/2019 sebanyak 37 siswa.

Dalam penelitian ini teknik sampling yang digunakan yaitu Nonprobability Sampling. Dan jenis sampling yang digunakan adalah Sampling Jenuh. Menurut Sugiyono (2015:124). Sampling jenuh adalah teknik penentuan sampel bila semua anggota populasi digunakan sebagai sampel (Ratnasari, 2016). Dalam penelitian ini peneliti menggunakan teknik pengumpulan data yang berupa tes, observasi dan dokumentasi. Teknik analisis data berupa analisis data adapun rumus yang digunakan uji normalitas awal (pretest) dan uji normalitas akhir (posttest). Kemudian menggunakan rumus uji $\mathrm{t}$ atau uji hipotesis Menurut Nilla, Retta, \& Sari (2017:160) peningkatan suatu penelitian pendidikan dapat dilihat dari sebelum dan sesudah proses pembelajaran. Untuk melihat peningkatan tersebut dilakukan melalui analisis terhadap skor gain ternormalisasi $\langle\mathrm{g}\rangle$, selanjutnya uji ketuntasan belajar berupa uji ketuntasan belajar individual dan uji ketuntasan belajar klasikal. Dengan kriteria nilai rata-rata hasil belajar siswa $\geq$ $85 \%$ dari jumlah yang mendapat nilai diatas KKM (65).

\section{Hasil dan Pembahasan}

Hasil penelitian di SD N Pleburan 04 Kota Semarang pada semester II tahun ajaran 2018/2019 pada kelas II dengan jumlah 37 siswa. Kegiatan pembelajaran pada penelitian ini adalah menerapkan model pembelajaran Talking Stick berbantu media PAPEGI terhadap hasil belajar Matematika siswa kelas II SD N Pleburan 04 Kota Semarang.

Penelitian ini diawali dengan membuat soal uji coba instrumen di SD Muhammadiyah 17 Semarang pada kelas II. Soal yang diuji cobakan sebanyak 50 butir soal pilihan ganda pada mata pelajaran matematika materi perkalian dan pembagian. Hasil dari uji coba soal dianalisis untuk mengetahui jumlah soal yang memenuhi kriteria validitas, reliabilitas, daya pembeda dan taraf kesukaran. Dari jumlah 50 soal uji coba yang memenuhi kriteria valid, reliabel, daya pembeda dan taraf kesukaran adalah 28 soal, dari 28 soal uji coba diambil 25 soal yang kemudian dijadikan soal pretest dan soal posttest.

Data penelitian ini diperoleh dari data hasil pretest dan posttest. Nilai pretest diperoleh dari nilai tes siswa sebelum diberi perlakuan yaitu pembelajaran menggunakan model pembelajaran talking stick berbantu media PAPEGI dan nilai posttest diperoleh dari nilai tes siswa setelah diberi perlakuan yaitu pembelajaran dengan menggunakan model pembelajaran talking stick berbantu media PAPEGI. Nilai prestest dan nilai posttest diperoleh dari tes yang diberikan, yaitu berupa soal pilihan ganda yang berjumlah 25 soal. Sampel penelitian berasal dari semua populasi kelas II yang berjumlah 37 siswa.

Tabel 1. Data hasil Pretest dan Posttest Nilai Pretest dan Posttest

\begin{tabular}{cccc}
\hline Jenis Tes & Nilai Tertinggi & Nilai Terendah & Rata - Rata \\
\hline Pretest & 88 & 24 & 56,1 \\
Posttest & 100 & 52 & 82,4 \\
\hline
\end{tabular}

(Sumber: Data Hasil Penelitian, 2019)

Berdasarkan Tabel 1. nilai pretest dan posttest menunjukkan skor rata-rata hasil belajar siswa yang didapatkan pada pretest sebesar 56,1 dan setelah dilakukan posttest didapatkan nilai rata-rata sebesar 82,4 . Terdapat perbandingan skor rata-rata antara sebelum diberikan perlakuan menggunakan model talking stick berbantu media PAPEGI dalam pembelajaran matematika materi perkalian dan pembagian dan sesudah diberikan perlakuan menggunakan model talking stick berbantu media PAPEGI dalam pembelajaran matematika materi perkalian dan pembagian mengalami peningkatan rata-rata hasil belajar siswa. 


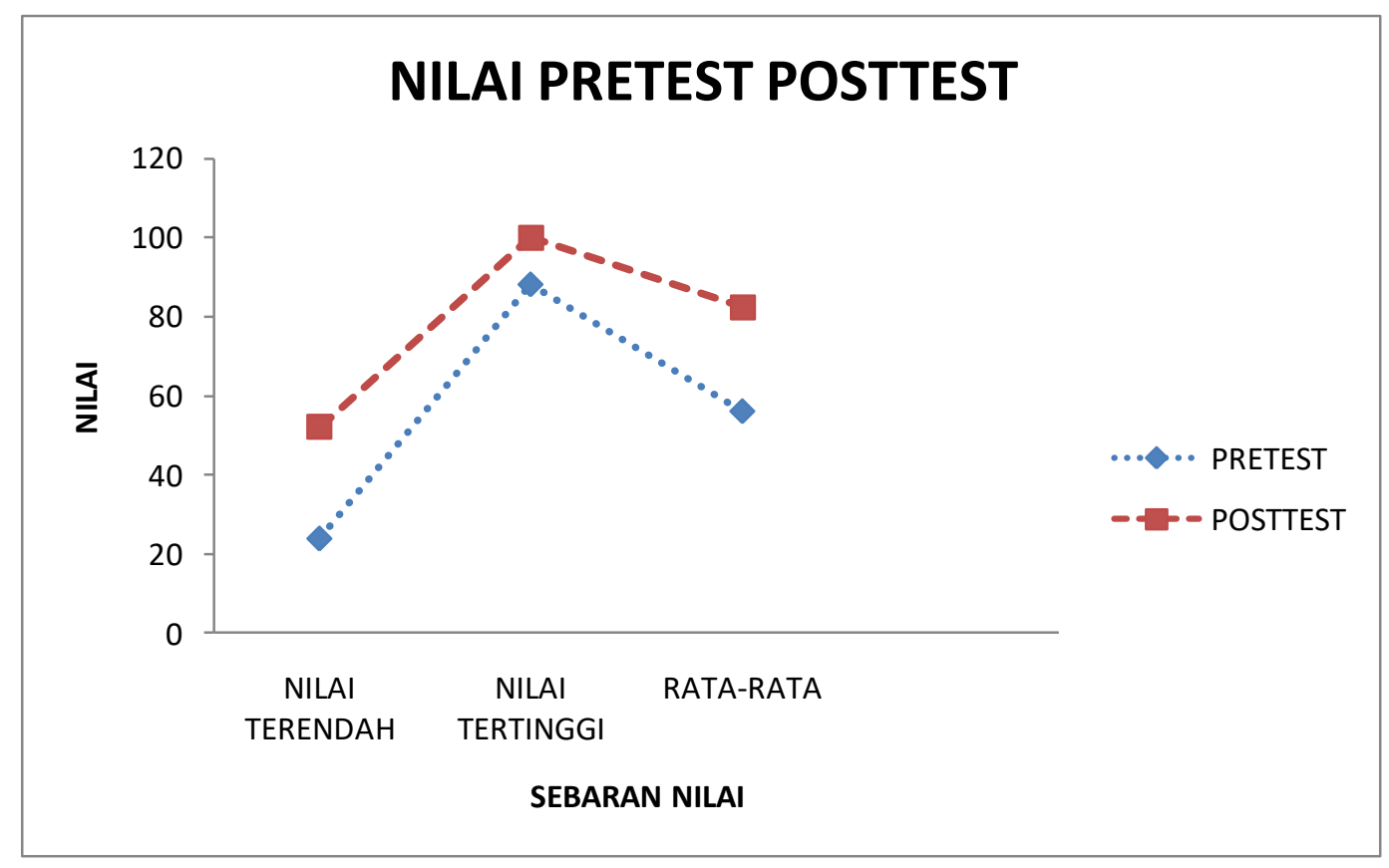

Gambar 2.

Diagram Pretest Posttest

Berdasarkan Gambar. 2 tampak perbedaan rata-rata pretest dan posttest siswa kelas II SD N Pleburan 04 Kota Semarang. Rata-rata nilai pretest sebesar 56,1 sedangkan rata-rata nilai posttest sebesar 82,4. Dapat dilihat bahwa dari 37 siswa kelas II SD N Pleburan 04 Kota Semarang, hasil pretest sebelum diberikan perlakuan pada pembelajaran matematika materi perkalian dan pembagian hanya 11 siswa yang dinyatakan tuntas dan 26 siswa tidak tuntas. Sedangkan pada hasil posttest yang diambil setelah diberikan perlakuan menggunakan model pembelajaran talking stick berbantu media PAPEGI sejumlah 32 siswa yang dinyatakan sudah tuntas dan 5 siswa yang dinyatakan tidak tuntas. Hal ini menunjukkan bahwa nilai posttest siswa yang diberi perlakuan menggunakan model pembelajaran talking stick berbantu media PAPEGI lebih baik dibandingkan dengan nilai pretest siswa tanpa diberi perlakuan menggunakan model pembelajaran talking stick berbantu media PAPEGI dan ketuntasan siswa pada hasil posttest lebih tinggi dibandingkan dengan hasil pretest.

Hasil Uji Normalitas Pretest (Awal) memperoleh Lhitung $=0,097$ dengan N (jumlah siswa) $=37$ dengan taraf signifikan $5 \%$, didapat Ltabel $=0,145$. Bandingkan Lhitung dengan nilai kritis L(Ltabel) untuk uji lilliefors, karena Lhitung $<$ Ltabel atau $(0,097<0,145)$ maka Ho diterima. Jadi, data nilai pretest berasal dari populasi berdistribusi normal. Sedangkan hasil Uji Normalitas Posttest (Akhir) memperoleh Lhitung $=$ 0,128 dengan $N$ (jumlah siswa) $=37$ dengan taraf signifikan $5 \%$, didapat $L$ tabel $=0,145$. karena $L_{\text {hitung }}<$ Ltabel $(0,128<0,145)$ maka Ho diterima. Jadi, data nilai posttest hasil belajar berasal dari populasi berdistribusi normal.

Tabel 2. Hasil Penghitungan Uji T

\begin{tabular}{cccccccc}
\hline Subjek & $\begin{array}{c}\text { Hasil } \\
\text { Belajar }\end{array}$ & $\begin{array}{c}\text { Rata- } \\
\text { rata }\end{array}$ & N & Md & $\sum_{x^{2} d}$ & $\mathbf{t}_{\text {hitung }}$ & $\mathbf{t}_{\text {tabel }}$ \\
\hline $\begin{array}{c}\text { Kelas II SD N } \\
\text { Pleburan 04 }\end{array}$ & Pretest & 56,1 & 37 & 26,37838 & $\begin{array}{c}2606,70 \\
27\end{array}$ & 18,856 & 2,021 \\
Kota Semarang & Posttest & 82,4 & & & & \\
\hline
\end{tabular}

Analisis Uji t disajikan pada Tabel 2. menunjukkan bahwa rata-rata siswa pada kondisi awal sebelum diberi perlakuan dengan menggunakan model pembelajaran talking stick berbantu media PAPEGI sebesar 56,1 sedangkan rata-rata siswa sesudah diberi perlakuan dengan model pembelajaran talkingstick berbantu media PAPEGI sebesar 82,4. Dari data analisis uji t diperoleh thitung $=18,856$ selanjutnya dibandingkan dengan tabel $=2,021$ dengan $\mathrm{db}=37-1$ pada taraf signifikan $5 \%$. Hasil ini menunjukkan bahwa thitung $>$ tabel yaitu 18,856 > 2,021 maka (hipotesis awal) Ho ditolak dan (hipotesis akhir) Ha 
diterima, sehingga dapat disimpulkan bahwa hasil belajar sebelum (pretest) dan sesudah (posttest) menggunakan model pembelajaran talkingstick berbantu media PAPEGI tidak sama, artinya ada pengaruh positif dalam penggunaan model pembelajaran talking stick berbantu media PAPEGI terhadap hasil belajar matematika siswa kelas II SD N Pleburan 04 Kota Semarang.

Tabel 3. Uji Indeks Gain

\begin{tabular}{cc}
\hline Jumlah Siswa & Kriteria \\
\hline 16 & Tinggi \\
21 & Sedang \\
0 & Rendah \\
\hline
\end{tabular}

Berdasarkan data pada Tabel 3. menunjukkan bahwa terdapat peningkatan dari nilai pretest dan posttest. Berdasarkan kategori nilai Gain (Kesumawati, 2017:160) yaitu dari 37 siswa, 21 siswa mengalami peningkatan dengan kriteria sedang $(0,30 \leq \mathrm{g} \geq 0,70)$, 16 siswa mengalami peningkatan dengan kriteria tinggi $(0,70 \leq \mathrm{g} \geq 1,00)$, dan tidak ada siswa yang mengalami peningkatan dengan kriteria rendah.

Tabel 4. Uji Ketuntasan Klasikal Pretest dan Posttest

\begin{tabular}{ccc}
\hline & Pretest & Posttest \\
\cline { 2 - 3 } Jumlah siswa & 37 & 37 \\
Siswa tuntas & 11 & 32 \\
Siswa tidak tuntas & 26 & 5 \\
KBK & $30 \%$ & $86 \%$ \\
\hline Keterangan & TIDAK TUNTAS & TUNTAS \\
\hline
\end{tabular}

Berdasarkan Tabel 4. ketuntasan belajar klasikal Pretest sebesar 30\% dengan keterangan tidak tuntas sedangkan ketuntasan belajar klasikal Posttest sebanyak $86 \%$ dengan keterangan tuntas. Jadi terdapat peningkatan saat Pretest dan Posttest.

Peneliti melakukan uji normalitas untuk mengetahui apakah siswa kelas II SD N Pleburan 04 Kota Semarang berdistribusi normal atau tidak. Penghitungan uji normalitas didasari oleh hasil pretest dan posttest. Uji normalitas pretest mendapatkan hasil berdistribusi normal dengan perhitungan data dari nilai pretest diperoleh $\mathrm{L}_{0}=0,097$ dengan $\mathrm{n}=37$ dan taraf nyata $\alpha=0,05$, dari daftar nilai kritis $\mathrm{L}$ didapat Ltabel $=0,145$. Karena L0 < Ltabel yaitu 0,097 < 0,145 maka H0 diterima. Uji coba Posttest mendapat hasil berdistribusi normal dengan perhitungan data dari nilai posttest diperoleh $\mathrm{L}_{0}=0,128$ dengan $\mathrm{n}=37$ dan taraf signifikan $\alpha=0,05$ dari daftar nilai kritis $\mathrm{L}$ didapat $\mathrm{L}_{\text {tabel }}=0,145$. Karena $\mathrm{L}_{0}<\mathrm{L}_{\text {tabel }}$ yaitu $0,128<0,145$ maka $\mathrm{H}_{0}$ diterima.

Tahap berikutnya peneliti melakukan perhitungan uji t untuk mendapatkan hasil analisis dari uji hipotesis peneliti. Hasil analisis akhir yang dilakukan dengan menggunakan uji t menunjukkan bahwa hasil thitung $=18,856$ selanjutnya dibandingkan dengan ttabel $=2,021$ dengan $\mathrm{db}=37-1$ pada taraf signifikan $5 \%$. Hasil ini menunjukkan bahwa thitung $>$ tabel yaitu 18,856 > 2,021 maka $\mathrm{H}_{0}$ ditolak dan Ha diterima, sehingga dapat disimpulkan bahwa ada pengaruh positif penggunaan model pembelajaran talking stick berbantu media PAPEGI kelas II SD N Pleburan 04 Kota Semarang. Penggunaan model pembelajaran talking stick berbantu media PAPEGI merupakan alternatif solusi dari pembelajaran yang tidak menggunakan model dan media pembelajaran. Model pembelajaran talking stick berbantu media PAPEGI dapat menciptakan suasana belajar yang menyenangkan, aktif, dan menumbuhkan minat belajar.

Langkah terakhir yang dilakukan dalam penelitian ini adalah menghitung peningkatan belajar individu. Peningkatan belajar individu dapat dilihat pada tabel peningkatan belajar nilai pretest dan posttest. Untuk peningkatan hasil belajar diperoleh hasil peningkatan belajar dari nilai rata-rata pretest $=56,1$ dan nilai rata-rata posttest $=82,4$. Nilai aktivitas belajar siswa juga meningkat terlihat pada pertemuan pertama nilai aktivitas siswa dalam belajar mendapatkan hasil 66, pertemuan kedua mendapatkan hasil 77 dan pertemuan ketiga mendapatkan nilai 89. Siswa lebih berani dan percaya diri dalam menjawab pertanyaan. Hal ini dikarenakan sudah diterapkan pembelajaran menggunakan model pembelajaran talking stick berbantu media PAPEGI. Karena dengan model pembelajaran talking stick siswa dituntut untuk berbicara/mengemukakan pendapatnya untuk menjawab soal sebagai hukuman karena telah mendapatkan tongkat (stick). Dengan media PAPEGI siswa lebih mudah memahami materi pembelajaran. Siswa lebih aktif dan merasa senang saat kegiatan belajar mengajar. Berdasarkan analisis 
hasil belajar siswa dapat disimpulkan bahwa ada pengaruh positif penggunaan model pembelajaran talking stick berbantu media PAPEGI terhadap hasil belajar siswa kelas II SD N Pleburan 04 Kota Semarang. Jadi terdapat relevansi dengan penelitian ini yaitu sama-sama bertujuan untuk meningkatkan hasil belajar matematika siswa dengan menggunakan model pembelajaran Talking Stick. Hanya saja penelitian ini berbantuan dengan media PAPEGI (Papan Perkalian Pembagian).

\section{Simpulan dan Saran}

Berdasarkan hasil penelitian yang sudah dilakukan dapat disimpulkan bahwa model pembelajaran talking stick berbantu media PAPEGI berpengaruh terhadap hasil belajar matematika siswa kelas II SD N Pleburan 04 Kota Semarang. Hal ini ditunjukkan dengan meningkatnya hasil belajar siswa dari hasil belajar yang rendah pada nilai pretest hingga pada nilai yang tinggi atau meningkat pada hasil belajar posttest karena adanya perlakuan yang diberikan dalam pembelajaran menggunakan model pembelajaran talking stick berbantu media PAPEGI. Berdasarkan analisis data bahwa model pembelajaran Talking Stick berbantu media PAPEGI berpengaruh terhadap hasil belajar matematika siswa kelas II SD N Pleburan 04 Kota Semarang. Hal tersebut dapat dilihat pada uji-t menunjukkan bahwa rata-rata siswa pada kondisi awal sebelum diberi perlakuan dengan menggunakan model pembelajaran talking stick berbantu media PAPEGI sebesar 56,1 sedangkan rata-rata siswa sesudah diberi perlakuan dengan model pembelajaran talkingstick berbantu media PAPEGI sebesar 82,4. Dari data analisis uji $\mathrm{t}$ diperoleh thitung $=18,856$ selanjutnya dibandingkan dengan tabel $=2,021$ dengan $\mathrm{db}=37-1$ pada taraf signifikan $5 \%$. Hasil ini menunjukkan bahwa thitung $>$ tabel yaitu 18,856 > 2,021 maka Ho ditolak dan Ha diterima, sehingga dapat disimpulkan bahwa hasil belajar sebelum (pretest) dan sesudah (posttest) menggunakan model pembelajaran talkingstick berbantu media PAPEGI tidak sama, artinya ada pengaruh positif dalam penggunaan model pembelajaran talking stick berbantu media PAPEGI terhadap hasil belajar matematika siswa kelas II SD N Pleburan 04 Kota Semarang.

\section{Daftar Rujukan}

Amir, A. (2014). Pembelajaran Matematika SD Dengan Menggunakan Media Manipulatif. Forum Paedagogik, 1(1).

Anggarini, dkk. (2019). Keefektifan Model Two Stay Two Stray Berbantu Media Roda Pintar Matematika Terhadap Hasil Belajar. Journal of Primary and Children's Education, 2(1).

Cahyani, Sisvina Dian., dkk. (2019). Pengaruh Model Pembelajaran Creative Problem Solving terhadap Kemampuan Pemecahan Masalah Matematis Siswa. Jurnal Mimbar PGSD, 7(2).

Huda, F. (2017). Penerapan Model Pembelajaran Talking Stick Meningkatkan Hasil Belajar Pokok Bahasan Pancasila Sebagai Dasar Negara Republik Indonesia Kelas VI Tahun Pelajaran 2017/2018. Jurnal PTK Dan Pendidikan, 3(2), 45-54.

Janah, N. (2018). Self Confidence Dalam AKtivitas Belajar Matematika Siswa. Jurnal Pendidikan Matematika, 31(2).

Nilla, K., Retta, A. M., \& Sari, N. (2017). Pengantar Statistika Penelitian. Depok: PT Raja Grafindo Persada.

Ratnasari, L. (2016). Pengaruh Leverage, Likuiditas, Ukuran Perusahaan Terhadap Profitabilitas Pada Perusahaan Otomotif Di BEI. Jurnal Ilmu Dan Riset Manajemen, 5(6).

Rusman. (2017). Belajar \& pembelajaran. Jakarta: KENCANA.

Sudharto, S., Suharno, K., \& Soegeng. (2013). Pengantar Ilmu Pendidikan. Semarang: FIP IKIP Semarang.

Sugiyono, M. (2015). Metode Penelitian Pendidikan. Bandung: Alfabeta.

Susanto. (2016). Teori Belajar dan Pembelajaran. Jakarta: Prenada Media Grup.

Wijanarko, Y. (2017). Model Pembelajaran Make A Match Untuk Pembelajaran IPA yang Menyenangkan. Jurnal Taman Cendekia, 1(1).

Wulansari, D. (2017). Pengaruh Model Pembelajaran Talking Stick Didukung Media Diorama terhadap Hasil Belajar Ilmu Pengetahuan Sosial Materi Perkembangan Teknologi Transportasi serta Pengalaman Menggunakannya pada Siswa Kelas IV SDN Tambakrejo Kec. Gurah Kab. Kediri Tahun Pela. Simki-Pedagogia, 1(11), 1-12. 